\title{
REDD+ policy translation and storylines in Laos
}

\author{
Sabaheta Ramcilovic-Suominen ${ }^{1}$ \\ Iben Nathan \\ Natural Resources Institute Finland, Finland \\ University of Eastern Finland, Finland \\ University of Copenhagen, Denmark
}

\begin{abstract}
This article examines the (re)production of discourses and storylines in the process of policy translation of Reducing Emissions from Deforestation and Forest Degradation (REDD+) in Laos. Applying the concepts of policy discourses and policy translation, we first identify the prominent storylines at the various governance levels in Laos. Second, we compare and contrast these storylines with the global REDD+ discourses. Further, we discuss how different actors' capacities and political agendas shape REDD+ storylines at different levels of governance. We find that national and sub-national storylines portray REDD+ mainly as a tool for supporting Laos' forestry strategy and sustainable forest management; for capacity-building and donor funding; and for village forest management and education of villagers. At the village level, many see REDD+ as a project for various political elites and external actors to control forests and cheat villagers. We conclude that, while globally there is increasing attention to civic-environmentalism in REDD+, neoliberalist and techno-managerial discourses still dominate. At the village level, however, civic-environmentalist ideas, such as social safeguards, benefit sharing, and equity largely disappear and two opposing discourses emerge representing anti-civic ideas and REDD+ resentment. Furthermore, while techno-managerial ideas permeate all levels in Laos, neoliberalist ideas in terms of carbon trading are almost absent. During policy translation, REDD+ thus transforms into "just another" top-down development project. This serves the interest of Laos's techno-managerial elite well, but has little positive prospect for local people and forests. In this perspective, the lack of alternative discoursecoalitions promoting non-carbon benefits, social safeguards, and equity is striking.
\end{abstract}

Key Words: REDD+, Laos, policy translation, environmental discourses, neoliberalism, civic environmentalism

\section{Résumé}

Cet article examine la (re) production de discours et de scénarios dans le processus de traduction des politiques de «Réduction des émissions dues à la déforestation et à la dégradation des forêts» (REDD +) au Laos. En appliquant les concepts de discours politiques et de traduction politique, nous identifions d'abord les principaux récits aux différents niveaux de gouvernance au Laos. Deuxièmement, nous comparons et contrastons ces récits avec les discours mondiaux REDD +. De plus, nous discutons de la façon dont les capacités et les agendas politiques des différents acteurs façonnent les scénarios REDD +. Nous constatons que les scénarios nationaux et infranationaux présentent la REDD + principalement comme un outil pour soutenir la stratégie forestière du

\footnotetext{
${ }^{1}$ Dr. Sabaheta Ramcilovic-Suominen, Natural Resources Institute Finland and Department of Geographical and Historical Studies, University of Eastern Finland, Finland. Email: sabaheta.ramcilovik-suominen "at" luke.fi. Dr. Iben Nathan, Associate Professor, Department of Food and Resource Economics (IFRO), University of Copenhagen, Denmark. Email: in "at" ifro.ku.dk. Acknowledgements: The first author gratefully acknowledges the funding by the Academy of Finland (grant number 285984). The authors would like to thank to all respondents who took part in the study, and Sebastian Koch for his help, insights and comments related to REDD+ and the CliPAD project for earlier drafts of this paper. Thanks also to Thomas Okfen for helping with fieldwork coordination, and to research assistants Houathor Youayee and Tongyang Ardphasoukmoua for helping with data collection and translations. Many thanks to Nick Quist Nathaniels for help with the English language. Finally, the authors thank the two reviewers and the editors of this Special Issue for their comments. This is the third article in Adeniyi Asiyanbi and Jens Friis Lund (eds.). 2020. "Stabilizing a policy: reproducing REDD+", Special Section of the Journal of Political Ecology 27: 378-495.
} 
Laos et la gestion durable des forêts. En outre, pour le renforcement des capacités et le financement des donateurs; et pour la gestion des forêts villageoises et l'éducation des villageois. Au niveau du village, beaucoup voient la REDD + comme un projet pour les élites politiques et les acteurs externes pour contrôler les forêts et tromper les villageois. Nous concluons que, alors que dans le monde il y a une attention croissante au civismeenvironnementalisme dans la REDD +, les discours néolibéralistes et technogestionnaires dominent toujours. Au niveau du village, cependant, les idées civico-environnementalistes, telles que les garanties sociales, le partage des avantages et l'équité, disparaissent largement et deux discours opposés émergent, représentant des idées anti-civiques et le ressentiment REDD +. De plus, alors que les idées techno-managériales imprègnent tous les niveaux au Laos, les idées néolibéralistes en termes d'échange de carbone sont presque absentes. Lors de la traduction des politiques, REDD + se transforme ainsi en «juste un autre» projet de développement descendant. Cela sert bien l'intérêt de l'élite techno-gestionnaire du Laos, mais a peu de perspectives positives pour les populations locales et les forêts. Dans cette perspective, le manque d'alternatives discours-coalitions promouvant les avantages non liés au carbone, les garanties sociales et l'équité est frappant.

Mots clés: REDD+, Laos, traduction des politiques, discours environnementaux, néolibéralisme, environnementalisme civique

\section{Resumen}

Este artículo examina la (re)producción de los discursos y las líneas argumentales en el proceso de traducción de políticas acerca de la Reducción de las Emisiones Derivadas de la Deforestación y la Degradación de Bosques (REDD+) en Laos. Primero, aplicando los conceptos de discursos de políticas y traducción de políticas, identificamos las líneas argumentales prominentes en los diferentes niveles de gobernanza en Laos. Segundo, comparamos y contrastamos estas líneas argumentales con los discursos globales de la REDD+. Además, discutimos como las capacidades y las agendas políticas de los diferentes actores determinan las líneas argumentales acerca de la REDD+ en los distintos niveles. Mostramos que las líneas argumentales nacionales y sub-nacionales retratan la REDD+ principalmente como herramienta de apoyo para la estrategia forestal y el manejo sostenible forestal en Laos; para la capacitación y la financiación de donantes; y para el manejo forestal y educación a nivel de las aldeas. Como conclusión, planteamos que a pesar del incipiente atención a un ambientalismo cívico a nivel global, dominan los discursos neoliberales y tecno-gerenciales. A nivel de aldeas, sin embargo, las ideas cívico-ambientales, tales como salvaguardias sociales, distribucion de beneficios, y equidad, generalmente desaparecen dando lugar a dos discursos opuestos emergentes representando ideas anticívicas y de resentimiento con la REDD+. Además, mientras que las ideas tecno-gerenciales impregnan todos los niveles de gobernanza en Laos, las ideas neoliberales en términos de comercio de carbono quedan prácticamente ausentes. En la traducción de políticas, la REDD+, por lo tanto, se transforma en "un proyecto de desarrollo más” de implementación desde arriba hacia abajo. Esto sirve los intereses del élite tecno-gerencial de Laos mientras que contribuye poco o nada en las vidas de la gente local y los bosques. Desde esta perspectiva, es llamativa la falta de coaliciones de discurso alternativas promoviendo beneficios no ligados a carbono, salvaguardias sociales y equidad.

Keywords: REDD+, Laos, traducción de políticas, discursos ambientales, neoliberalismo, ambientalismo cívico

\section{Introduction: REDD+ academic debates and environmental policy discourses}

REDD+ is a mechanism aiming at mitigating climate change by creating financial value for carbon stored in forests having evolved within the United Nation's Framework Convention for Climate Change, UNFCCC (UNREDD 2017). Although a variety of actors are currently involved in preparing and implementing REDD+ all over the world, the United Nations' REDD+ program (UN-REDD+) and the World Bank's Forest Carbon Partnership Facility (FCPF) remain the largest platforms for REDD+. These actors support national REDD+ programs in more than 50 countries, including Laos ${ }^{2}$, with over 350 projects and US\$9.8 billion pledged under the UNFCCC alone (Canby et al. 2014; EDF and Forest Trends 2018; Lee and Pistorius 2015). This article seeks an understanding of how various actors at national, subnational, and local level in Laos "translate" the global discourses on REDD+ and how these translations affect REDD+ implementation. More specifically, it

${ }^{2}$ Lao Peoples' Democratic Republic 
examines the storylines that emerge at national, provincial/district, and village levels in the context of REDD+ implementation in Laos. We evaluate these storylines against the global REDD+ discourses, and discuss the implications for REDD+ in Laos and beyond. We base our study on the assumption that the effects of a policy depend on its interpretation and resulting practices (Jasanoff and Wynne 1998; Winkel et al. 2017). Therefore, one of the keys to understanding the potential of REDD+ to deliver on its policy goals is an analysis of the discourses and narratives connected to REDD+ implementation at all levels. By REDD+ implementation in Laos we refer to two major activities: the REDD+ policy process, including policy and institutional reforms, which currently mainly happens at the national level, and REDD+ pilot project implementation in the study areas.

Two meta-discourses have been particularly important in shaping global discourses on REDD+ (Nielsen 2014; Arts et al. 2010). The first is ecological modernization, founded on neoliberalist and technocraticmanagerial ideas (Hajer 1995). Many scholars have pointed to economic neoliberalism as a basic feature of REDD+ at all levels (Lohmann 2012; Dressler et al. 2015; Fletcher et al. 2016), and neoliberalist ideas are inherent to the definition of REDD+ as a mechanism creating financial value for carbon stored in forests. Neoliberalist ideas also reveal themselves in the assumption that financial incentives can change public and private decisions that would otherwise lead to conversion of tropical forests to other land uses since, as some REDD+ proponents' argue, carbon markets can help create financial value from carbon stored in forest (Duchelle et al. 2018; Simonet et al. 2018, UN-REDD 2018). The techno-managerial approach appears, for instance, when REDD+ proponents see forests as carbon stocks and sinks; when they emphasize the role of experts and advanced technology in relation to monitoring, reporting, and verifying avoided emissions; and when they search for 'win-win' solutions (Bäckstrand and Lövbrand 2006; Di Gregorio et al. 2017; Nielsen 2014).

The second meta-discourse is civic environmentalism which represents ecological and social dimensions of environmental politics (Bäckstrand and Lövbrand 2006; Nielsen 2014). Civic environmentalists often criticize neoliberalist and techno-managerial ideas. Instead, they are concerned with environmental justice, equity, local knowledge, and inclusion of marginalized people (Arts et al. 2010; Bäckstrand and Lövbrand 2006). When REDD+ first evolved, civic environmentalism was rather weak, but it has gained importance over time. There is thus a growing recognition among policymakers of the need for attending to "civic" and environmental aspects such as poverty reduction, participation, inclusion of indigenous and other marginalized people, and consideration for biodiversity. Current agreements under the UNFCCC take civic environmentalist aspects into concern under 'social safeguards' and Free Prior Informed Consent (FPIC) in REDD+ (Aicher 2014; Arhin 2014; COP 16/ 2010; Paris Agreement 2015).

The academic debate on REDD+ increasingly encompasses criticism of this mechanism. More radical criticism discards the very assumptions and paradigms that have shaped REDD+. The key argument is that neoliberalism and techno-managerial approaches cannot solve the global environmental problems we face today because these very logics caused the problems in the first place (Dressler et al. 2015; Fletcher et al. 2016; Hajer 1995). This literature points to trade-offs instead of synergies between economic growth, sustainable forest management, and equity in REDD+ (Dawson et al. 2018; Fox et al. 2011; Milne et al. 2019; Nathan and Pasgaard 2017; Ramcilovic-Suominen 2019). Finally, there is the point of view that REDD+ is "carbon colonialism" (Fletcher et al. 2016), and a development fad (Lund et al. 2017).

Moderate criticism often addresses the question of whether and how REDD+ can achieve its own mitigation objectives, and how the implementation of REDD+ affects environmental and equity goals (Ece et al. 2018; Milne et al. 2019; McDermott 2014; Saeed et al. 2018). For instance, some scholars point to leakage, lack of additionality, and technical problems related to monitoring, reporting, and verification as factors that may undermine the effectiveness of REDD+ (Gupta et al. 2012; Ingalls et al. 2018; Mertz et al. 2018). Following the argument of Ferguson and Lohmann (1994), some claim that REDD+ projects may end up depoliticizing climate change mitigation, in that these projects cannot address politically sensitive drivers of deforestation, such as large-scale international land concessions, thereby undermining effectiveness (Myers et al. 2018; Nathan and Pasgaard 2017). 
Studies of REDD+ in Zanzibar (Benjaminsen 2017), Nepal (Khatri et al. 2018), Kenya (Chomba et al. 2016), and Laos (Pasgaard 2015; Ramcilovic-Suominen 2019) point to equity problems in that they find that REDD+ policy is being adapted and implemented at the local level based on existing practices, land tenure systems, and within the existing actor coalitions, which maintain or reinforce existing inequalities and power structures. DiGregorio et al. (2013) conclude that, even though there is an increasing acceptance of equity and social safeguards and of involving key stakeholders in meetings and village consultations, this is, in practice, mainly just about "ticking boxes." In an analysis of frames and discourses about global REDD+ objectives, Vije et al. (2016) suggest that while non-carbon benefits are prominent in REDD+ policy documents, these documents rarely provide clear definitions of what these benefits are.

Hence, academic debates and policy discourses have mainly revolved around the basic assumptions of REDD+ and around the question of its local implementation. There has been comparatively less attention to the discourses and corresponding practices at national, sub-national, and local levels (Pasgaard 2015; Sanders et al. 2017). In other words, how do actors at these levels "translate" REDD+ and with what resulting practices? Especially in the case of Laos, the majority of empirical research focuses on the national policy level.

In examining the storylines that emerge at all policy levels, we contribute to the on-going debate about REDD+ and its potential - or lack of potential - for creating financial value for carbon stored in trees, while at the same time addressing social and environmental problems. We draw on primary data from a fieldwork, which the first author of this article carried out at national, provincial, district, and village levels in Laos in 2018. By comparing the different REDD interpretations and storylines with the prevailing global discourses, we aim at shedding light on the change of discourses across the domestic policy levels, including at the village level where empirical studies on REDD+ remain sparse.

We have structured the paper as follows. In section two, we present the empirical context of REDD+ implementation in Laos. In section three, we develop our theoretical and conceptual framework for studying environmental policy discourses. In section four, we present our research approach, area and methods. In section five, we present the results in terms of the storylines we identified during fieldwork. In section six, we discuss these storylines in relation to the two global REDD+ meta-discourses. Finally, in section seven, we conclude with implications for REDD+ practices and problem-solving capacities.

\section{Empirical context: status and institutional structure of REDD+ implementation in Laos}

Laos became a REDD+ partner to the FCPF as early as in 2008, and FCPF accepted the Laos Readiness Preparation Proposal in 2010, becoming one of the first REDD+ readiness countries (DoF 2010). Due to internally caused delay ${ }^{3}$, the Government of Laos received its first Readiness Grant of US\$3.6 million in 2015 (Dwyer and Ingalls 2015; MAF 2018; Vongvisouk et al. 2016). REDD+ gained further momentum when FCPF invited Laos into the Carbon Fund pipeline in March 2016 (Koch 2017).

Under the FCPF, Laos had only 18 months to elaborate a full Emission Reductions Program. Since then, the Ministry of Forest and Agriculture and the Department of Forestry together with their international development partners have focused on developing the required REDD+ policy framework. In June 2018, the FCPF Carbon Fund accepted the Laos Emission Reduction Program Document. This document and the Laos national REDD+ strategy propose reduction of greenhouse gas emissions from the forest sector starting in six selected pilot provinces including Houaphan, which is also the province that hosted our fieldwork.

Since 2009, the German Government started funding efforts by the Government of Laos to establish the institutional infrastructures for REDD+ through a project called Climate Protection through Avoided Deforestation (CliPAD). ${ }^{4}$ Since 2013, CliPAD has supported Houaphan province in preparing their Provincial

\footnotetext{
3 The standstill in REDD+ between 2010 and 2014 was due, among other things, to Ministerial rearrangements of the forestry sector (Koch 2017; Vongvisouk et al. 2016).

${ }^{4}$ The German Government funds CliPAD through the KfW development bank, and the German Development Agency (GIZ) coordinates and implements the project in cooperation with the Government of Laos (http://clipad-laos.org/)
} 
REDD+ Action Plan and District Action Plan in two districts (PRAP 2017). Houaphan therefore has the longest continual experience in piloting REDD+ activities in Laos. In Houaphan, CliPAD implements a so-called Village Forestry Component aimed at preparing 70 villages for REDD+ (GIZ 2016; Koch et al. 2015). This component incorporates various elements, including among others: Participatory Land Use Planning; Village Forest Management Plans, Village Development Funds for developing non-forest dependent livelihood activities; legally binding Village Forest Management Agreements and Regulations and the FPIC process (GIZ 2016; Koch et al. 2015). CliPAD's FPIC engages village authorities, villagers, and mass organizations such as the Lao Front for National Construction and the Lao Women Union to participate in a number of predefined REDD+ village meetings (GIZ 2016, 2017; Koch et al. 2015).

Relatively few studies have documented lessons learnt in this particular country context, especially at the subnational and village levels. Our study aims at documenting the storylines emerging at the REDD+ implementation piloting sites at the national, subnational (provincial and district), and local (village) levels, to understand how they emerge and what are their implications to REDD+ implementation. In the following, we explain the theoretical framework that has guided our study.

\section{Theoretical framework}

As mentioned, REDD+ has emerged within the global framework of UNFCCC, but implementation happens under very different national and subnational circumstances. In this sense, REDD+ is a policy on the move (Mukhtarov 2014). Actors with a stake in REDD+ implementation therefore need to translate REDD+ to make it fit with their specific beliefs, logics, and local political context. We are interested in how policy actors translate REDD+ through the emergence of storylines and what factors shape these storylines, since we assume that these storylines are decisive for REDD+ implementation and its outcomes (Hajer 1995, 2005). To examine and interpret REDD+ translations in the specific context of Laos, we have found it necessary to draw on and integrate two theoretical and conceptual frameworks: Argumentative Discourse Analysis and the ActorNetwork Theory's conceptualization of Policy Translation and its four moments of translation.

\section{Argumentative Discourse Analysis}

Discourses, storylines, and discourse coalitions are key concepts in Hajer's Argumentative Discourse Analysis (Hajer 1993, 1995, 2005). Hajer (2005: 300) defines a discourse as "an ensemble of ideas, concepts, and categories through which meaning is given to social and physical phenomena, and which is produced and reproduced through an identifiable set of practices."

Hajer $(1993,2005)$ argues that in order to cope with the lack of perfect information, uncertainty, and lack of knowledge, actors engage in argumentation and make use of storylines. Storylines relate to and construct discourses, but also attract people with their simplicity and ability to present complex phenomena, or debates in a simplistic way. Hajer (1995: 56) defines a storyline as "a generative sort of narrative that allows actors to draw upon various discursive categories to give meaning to specific physical or social phenomena". Storylines therefore allow actors to cope with uncertainty and bounded rationality. More importantly, however, storylines can be strategically applied to impose ideas, interpretations, and policy interests on others. Storylines thus provide actors with political tools to cooperate, negotiate, and compete with opposing views and interests (Hajer 1993), and through this process discourse coalitions are born. Hajer (2005: 302) defines discourse coalitions as a "groups of actors that (...) share the usage of a particular set of story lines over a particular period of time."

In sum, Argumentative Discourse Analysis allows us to understand how different policy actors frame and interpret a certain policy issue and how they position themselves in certain discourse coalitions. Moreover, it enables identifying and analyzing policy discourses and storylines (Milne et al. 2016; Rantala et al. 2015; Vijge 2015). The framework, however, is of less assistance for analyzing the complexity of contextual factors and local realities that predetermine how and why certain storylines, discourses and discourse coalitions prevail, often at the expense of others, in the context of policies on the move and policy translation. For this reason, we turn to the concept of policy translation as conceptualized within Actor-Network Theory. 


\section{Actor-Network Theory (ANT) and the Four Moments of Policy Translation}

The concepts of policy translation, or policies on the move, that have emerged from political and critical geography (Albrecht et al. 2017; Freeman 2009; Lendvai and Stubbs 2007; Mukhtarov 2014) are crucial contributions for expanding the more traditional approaches of policy transfer, diffusion, and lesson-drawing (Evans 2009; Dolowitz 2009; Dolowitz and March 2000). However, as our intention here is to capture the actors' abilities and interests to maneuver the policy space and not merely the outcomes of translation, and to remain open for introduction of new policy ideas and goals in the translation process, we adopt the concept of policy translation and the moments of translation in Actor-Network Theory (ANT).

The ANT looks at how/why a certain effect and change occurs, rather than the substance of the effect/change itself. ${ }^{5}$ Hence, we see ANT as a useful tool for unpacking the 'how and why questions' (Horowitz 2012; McElwee 2016; Sanders et al. 2017). In the context of policy translation, this means that ANT offers a toolkit for going beyond what is translated in attempting to understand how and why it is translated in a certain way.

Callon (1986a; 1986b) defines policy translation as a process that involves associating heterogeneous entities (e.g. civil society, villagers, or international development partners) and defining their identity, role to play, nature of bond, interactions, and task to follow within the actor-world. In order to understand the process of policy translation, he identifies four moments of translation. These moments constitute the different phases of translation during which actors negotiate identities, roles, and interactions. The first moment, problematization, involves defining the problem and its solutions. That is to say, policy actors according to their role and interests construct an issue as a problem, such as deforestation or illegal logging, and propose a solution, which is often complicated, such as certification schemes. The policy actors strategically establish themselves as an indispensable part of the solution known as obligatory passage points, through which the network must pass in order to solve the problem. The second moment of translation is interessement, which means that the policy actors directly or indirectly try to convince others to join their cause. They prescribe exact roles for the other actors as, e.g., initially planned in a program or project. They do so through a series of processes and strategies, such as providing resources and funding for those participating in their initiative. The third moment of translation, enrolment, goes a step further by putting the described roles of others into practice, or implementation. This requires multiple negotiations and trials materialized, for example, through pilot projects. The final stage of translation is mobilization. During this phase, policy actors aim at mobilizing wider groups of actors to follow them and the promoted approach.

Callon's conceptual framework draws attention to how policy actors translate, mobilize, change, and sometimes even reinvent policy aims during the four moments. Moreover, his framework can assist us in understanding the process in which policy actors engage, introduce their own ideas and interests along the way, and enroll others to follow their ideas, logics, storylines, discourses and eventually policy solutions (McElwee 2016; Horowitz 2012; Sanders et al., 2017). However, we highlight that the translation framework does little to account for the different levels of governance (local-global) and the different power relations that typically exist among actors from different governance levels (vertical power relations) and among actors from the same level of governance (horizontal power relations) nor on the effects these have on mobility of ideas. For this reason, we see the moments of translation and the Argumentative Discourse Analysis frameworks with their foci on the dynamics of the discourse building process and the power of discourse respectively, as highly complementary. We therefore apply them jointly in analyzing storyline production and actors' interests and motivations.

\footnotetext{
${ }^{5}$ ANT is associated with three authors: Bruno Latour (Latour 1999, 2005), Michel Callon (Callon 1986a,b) and John Law (Law 1999). In the field of science and technology studies, it deals with questions such as why we have science and technology that we do, instead of taking these for granted. The same approach is replicated in the social sciences realm, where some of the very basic ontological principles, which are largely taken for granted, are questioned. ANT has attracted substantial criticism mainly for its alternative ontological assumptions that render the century-old divisions in science irrelevant, including those between agency and structure, society and nature, human and non-human, content and context, truth and falsehood (Callon 1986a; Cressman 2009; Law 1999 and Ritzer Encyclopaedia 2004).
} 


\section{Research methods}

Our article draws on primary data from field research in Laos conducted during April and December 2017. The study was carried out in Houaphan province, where the REDD+ pilot project (CliPAD) is being implemented. Likewise, Sam Neua was selected as one of the two districts where CliPAD has its project activities. At the village level, the study was carried out in Baan Lao-Khmu and Baan Hmong villages, where CliPAD is implemented (village names are derived based on the villagers' ethnic backgrounds, Table 1). The selection of the district and villages was based on the practical arrangements and possibilities as assessed by the project staff.

\begin{tabular}{|l|l|l|}
\hline & Baan Lao-Khmu & Baan Hmong \\
\hline Location & $\begin{array}{l}\text { Closely located to the provincial capital } \\
\text { Sam Neua; recent asphalt road. }\end{array}$ & $\begin{array}{l}\text { Located in the high mountains with difficult } \\
\text { road conditions, market access, and accessibility. }\end{array}$ \\
\hline Ethnicity & $\begin{array}{l}\text { Mainly populated by Khmu a well- } \\
\text { integrated ethnic minority group resettled } \\
\text { there after liberation in 1975-and few Lao } \\
\text { Loum (Tai Dam) families who moved there } \\
\text { a decade ago. }\end{array}$ & $\begin{array}{l}\text { Populated by Hmong - an ethnic minority } \\
\text { known for its conflictual relations with the } \\
\text { government. }\end{array}$ \\
\hline $\begin{array}{l}\text { Livelihood } \\
\text { activities }\end{array}$ & $\begin{array}{l}\text { Engaged in both subsistence and cash } \\
\text { generating livelihood activities, including } \\
\text { laboring work at a brick-factory in a } \\
\text { neighboring village, silk weaving, biofuel } \\
\text { crops, rice farming, livestock, NTFs. }\end{array}$ & $\begin{array}{l}\text { Engaged mainly in subsistence livelihood } \\
\text { activities, including upland rice cultivation, } \\
\text { shifting cultivation, livestock, NTFPs. Less } \\
\text { diverse livelihoods, and less commonly engaged } \\
\text { in cash generating activities. }\end{array}$ \\
\hline $\begin{array}{l}\text { Availability } \\
\text { of } \\
\text { agriculture } \\
\text { land }\end{array}$ & $\begin{array}{l}\text { Lack of suitable land for shifting } \\
\text { cultivation, scarcity of paddy rice fields, } \\
\text { due to population increase and government } \\
\text { redistribution of paddy land. }\end{array}$ & $\begin{array}{l}\text { Substantial land for shifting cultivation } \\
\text { (10ha/household); area for paddy rice for half of } \\
\text { the households. }\end{array}$ \\
\hline $\begin{array}{l}\text { Village } \\
\text { forest } \\
\text { condition }\end{array}$ & $\begin{array}{l}\text { Village forests and forests around it } \\
\text { severely degraded in the past. }\end{array}$ & $\begin{array}{l}\text { Abundant village forest, by size and forest } \\
\text { cover. }\end{array}$ \\
\hline
\end{tabular}

Table 1: Profile of Baan Lao-Khmu and Baan Hmong villages.

In total, 78 interviews were conducted; 33 at central, 14 at subnational (provincial and district) and 31 at village level. At the national level, the first author conducted 19 interviews in English, while the remaining 14 were conducted in Lao with a help of research assistant. The interviews lasted between 1-1.5 hours each, and apart from one, all of them were recorded, transcribed and translated to English where needed. These were conducted with Lao state organizations (6), international development partners and technical assistance (8), domestic private sector (2), international private sector (3), domestic civil society organizations (6), international civil society organization (4), academia and research (4). At provincial and district levels we carried out open-ended qualitative interviews with respondents involved in the REDD+ process and CliPAD project activities. All respondents were members of REDD+ affiliated institutions and units established under the provincial and district government offices. They belonged to the provincial Task Force, provincial and district REDD+ Action Plan Units, and forest inspection units established under the relevant agencies. These interviews (duration between 45 and 75 minutes) were in Lao, and 12 of the interviews were recorded, transcribed and translated into English. At the village level, we conducted structured open-ended qualitative interviews (16 in Baan Lao-Khmu and 15 in Baan Hmong) in different languages, including Lao, Khmu and Hmong language. Respondents included village authority representatives, members of Village Land Use and Forest Management Committee and Village Development Funds, and villagers not affiliated with any of these village-level institutions. In Baan Lao-Khmu, the respondents were generally willing to be recorded (12 interviews were recorded), while in Baan Hmong only eight out of 15 respondents agreed to be recorded. 
Therefore, a significant part of the collected data includes interview notes. The interviews in both villages took between 50 and 80 minutes and were transcribed and translated into English.

A content analysis identified themes and storylines. Four key questions guided the analysis and storyline identification process:

1) What is REDD+ and how is it interpreted or framed?

2) What problems should REDD+ address?

3) What goals should REDD+ achieve?

4) How should costs and benefits be distributed among the different actors?

We examined those questions across the different administrative levels and were able to identify the storylines pertinent to the specific level.

\section{Results: REDD+ storylines in Laos and how they relate to the global meta-discourse}

In this section, we identify the storylines at the national, provincial/district, and at the village level in Laos. Table 2 sums up the dominant storylines at the different levels.

\begin{tabular}{|l|c|c|c|c|}
\hline Storylines at different level of governance: & National & $\begin{array}{l}\text { Sub- } \\
\text { national }\end{array}$ & $\begin{array}{l}\text { Village I } \\
\text { Lao-Khmu }\end{array}$ & $\begin{array}{c}\text { Village II } \\
\text { Hmong }\end{array}$ \\
\hline $\begin{array}{l}\text { 1) REDD+ as a financial tool to support sustainable } \\
\text { forest management in general and the Laos National } \\
\text { Forestry Strategy in particular. }\end{array}$ & + & + & $+/-$ & - \\
\hline $\begin{array}{l}\text { 2) REDD+ as capacity building process exclusively for } \\
\text { policy makers and project implementers. }\end{array}$ & + & + & - & - \\
\hline $\begin{array}{l}\text { 3) REDD+ addresses the forest degradation and other } \\
\text { challenges related to local people's use of forestlands. }\end{array}$ & + & $+/-$ & - & - \\
\hline $\begin{array}{l}\text { 3a Local communities cause deforestation and forest } \\
\text { degradation. }\end{array}$ & + & + & $+/-$ & - \\
\hline $\begin{array}{l}\text { 3b Local communities need awareness raising, } \\
\text { education, and training to understand the importance of } \\
\text { forest and sustainable forest management. }\end{array}$ & + & + & $+/-$ & - \\
\hline $\begin{array}{l}\text { 3c Local communities as agents who ought to benefit } \\
\text { from REDD+. }\end{array}$ & + & + & - & \\
\hline 4) REDD+ as a promise for donor funding. & + & + & & $+/-$ \\
\hline $\begin{array}{l}\text { 5) REDD+ as a village forestry project aiming at forest } \\
\text { conservation and alternative livelihoods. }\end{array}$ & $+/-$ & + & + & - \\
\hline 6) REDD+ copes with climate change & - & + & - & $+/-$ \\
\hline $\begin{array}{l}\text { 7) REDD+ educates villagers about the importance of } \\
\text { climate change and its linkages with forests. }\end{array}$ & + & + & + & + \\
\hline $\begin{array}{l}\text { 8) REDD+ as a project leading to dispossession of } \\
\text { forest communities and their loss of control over } \\
\text { forests. }\end{array}$ & - & - & $-/(+)$ & + \\
\hline
\end{tabular}

Table 2: Comparing the storylines at national, subnational and village levels in the Lao REDD+ process. 


\section{REDD+ storylines at the national level}

At the national level, we identified four dominating storylines. The first storyline concerned 1) REDD+ as a financial tool to support sustainable forest management in general and the Laos National Forestry Strategy in particular. According to this storyline, REDD+ provides funding for sustainable forest management plans across the country and for achieving the National Forestry Strategy objectives, such as $70 \%$ forest cover by 2020. All 33 national level respondents linked REDD+ with sustainable forest management and the National Forestry Strategy, and many of them defined REDD+ as a solution to the problem of deforestation and forest degradation. The following quote illustrates this storyline:

Yes, the Government wanted to achieve the $70 \%$ [forest cover by 2020] and at that time, you know, there was not enough funding to achieve that goal. The Government budget was not sufficient. It was very small. There was not enough money for us to achieve that goal. Then REDD was introduced, and we discussed if it could help us to close the budget gap to achieve $70 \%$ forest (respondent from government agency).

Some Civil Society Organization (CSO) respondents referred to a similar storyline, seeing REDD+ as a tool contributing to the national policy goal of increasing the forest cover. However, they highlighted that the Department of Forestry staff in reality channelled the funding "into its own pockets" and ensured "business as usual in forestry sector", with little changes in practice and policy goals. Particularly, they referred to the government's goal to limit the practice of shifting cultivation (Ramcilovic-Suominen 2019). The domestic CSOs also criticized REDD+ for being a highly exclusive process with participation only by the government and its development partners. Some respondents from the private sector shared the CSO position on the exclusivity of REDD+. However, they mainly explained their own lack of engagement in the process as due to a lack of market demand for carbon credits and the low market price of carbon combined with the high costs of setting up carbon monitoring methodology and certification schemes.

The second and related storyline relates to 2) REDD+ as a capacity building process exclusively for policy makers and project implementers. Examples of such capacities were, for instance, capacities for forest and land use mapping, land use planning and allocation, establishment of carbon reference levels, mapping of drivers of deforestation and forest degradation, development of national strategies, and reforms of legal and policy frameworks. Here, government respondents often pointed to the need for institutional reform and capacity building of (their own) government offices for operationalizing and implementing REDD+, such as for formulation of a national strategy or a strategy for monitoring and verification. Many CSO and private sector respondents felt excluded from the process. They argued that capacity building had been a waste of time and had only worked to camouflage benefit flows to the REDD+ elite, comprised by governmental officers and a handful of international development partners. They argued that the REDD+ processes had mainly benefited international consultants and that much funding had been spent on training and on government sector capacity building, while little had been done on the ground. As a respondent from Laotian CSO said, "So far, REDD+ money is spent on travelling and trainings. We, on the other hand, we have a project proposal with a detailed plan for rural development, but we lack funding. REDD+ money goes to trainings and conferences. They travel to the ASEAN countries, to Europe. There is a lot of money spent on that." In the same vein, a respondent from an international timber company said, "We have given up hope on REDD+. It is an exercise for consultants, and they are benefiting. We have seen no progress for 10 years now." Hence, while the arguments from government actors and international and domestic 'REDD+ experts' emphasized the capacity development efforts in the process, the civil society and private sector argued that what is portrayed as capacity building is rather a 'cash operating machine' for bureaucrats and development professionals (see storyline \#4).

A third storyline was that 3) REDD+ addresses forest degradation and other challenges related to local people's use of forestlands. We identified three arguments within this storyline. The first argument is that $a$ ) local communities cause deforestation and forest degradation. This argument was most prominent among government officers, but many international and domestic consultants and CSO members also reproduced it. According to this argument, local communities have no other alternatives for their livelihoods than engaging in 
forest-destructive activities, such as shifting cultivation, hunting, and fishing in protected areas (RamcilovicSuominen 2019). The second argument, which all types of interviewees shared, is that $b$ ) local communities need awareness raising, education, and training to understand the importance of forest and sustainable forest management. Government officers, in particular, tended to view local communities as engaged in harmful forest practices due to incompetence, lack of knowledge, and poverty. They also often considered the subsistence shifting cultivation practices of ethnic minority groups to be economically unviable, forest degrading, and backwards. The third argument portrays $c$ ) local communities as agents who ought to benefit from REDD+. Respondents from different respondent groups and affiliations at the national level reproduced this argument when justifying REDD+ activities although with different connotations. Respondents from government agencies tended to argue, for instance, that REDD+ helps develop the 'poverty stricken' mountainous areas in the northern part of the country. Some CSO respondents, on the other hand, raised concerns over the risk that forest dependent communities would lose access to forests in areas with REDD+ activities.

According to the fourth storyline, 4) $R E D D+$ is a promise for donor funding. Some development partners and civil society respondents talked about "drawing the REDD+ card" to access funding from donors. They viewed this as a strategy practiced by many national level actors while, in reality, these actors would continue previous projects and "business as usual." A number of extended international forestry projects included elements of REDD+ in their extended mandates, with the only difference from the previous project being the rhetoric of climate change mitigation through avoided emissions from forest degradation. In the words of a long-time international consultant and development partner in the country:

REDD+ payments are negligible (...) but REDD+ preparation phase pays off, especially because the REDD+ preparation does not cost that much and funding goes for administration and managing costs. So why not? REDD+ is useful, because it funds the GoL [Government of Laos] and the development partners to continue the work they want to do; and yes, part of that work is undeniably curbing the shifting cultivation and [is] mapping the forests. Those are the points where GoL and development partners agree. GoL wanted management plans, mapping, etc. now with REDD+ they can afford that. If you need to put your REDD+ cap on, why not do that.

\section{$R E D D+$ storylines at the subnational levels}

At the subnational levels, we traced storylines similar to the four we found at the national level. However, when provincial and district level respondents reproduced the first storyline about REDD+ as a financial tool they hardly ever referred to national level politics, the $70 \%$ forest cover goal, or training and conferences. Rather, they referred to REDD+ as providing them with funding and physical equipment for travelling to the villages to raise awareness, carry out land allocation plans, and facilitate forest law enforcement. A respondent from the District Forest and Agriculture Office said: "This project [CliPAD] helps us and our capacity to develop forest allocation plan and raise awareness on the importance of trees to villagers." A respondent from the Provincial Forest and Agriculture Office said:

[CliPAD] helps us to develop a clear legislation, and after that we can provide the communities with clear methods and orientation, so that they can understand and be able to accept and participate. Our plans are sometimes too technical for the communities to understand, and our expectations for them to accept and participate are too high. So the REDD+ project gives us the opportunity to get the communities' support, and we can build their capacity to participate and cooperate (...).

Largely, the respondents at the subnational levels emphasized the hardship experienced by the communities and their lack of alternative livelihoods more than the national level respondents did when reproducing the third storyline about REDD+ as a tool to address the challenges related to villagers practices. This led them to focus more on argument 3c) about the need for providing benefits and alternative livelihood 
schemes for forest communities; but also on arguments 3a and 3b concerning local communities degrading forests and the need to educate them especially with regard to forest protection.

Three additional storylines emerged from the interviews at the subnational levels. The first was the storyline about 5) REDD+ as a village forestry project aiming at forest conservation and alternative livelihoods. This storyline equated REDD + with village forestry activities, such as demarcation and allocation of forestland, definition and implementation of village forest regulations, and introduction of alternative livelihood activities for villagers engaged in shifting cultivation. For instance, a provincial level respondent explained that:

The main activity in REDD is the land use allocation, because it allocates land use in detail for the villages. For example, villagers can know how to use and where to use forest, where and how to farm, etc. Villagers will not come and destroy anymore. It will be the same answer that I gave before: as villagers get income for alternative livelihood activities they will do less upland rice [a synonym for shifting cultivation] and this will save forests.

Many other respondents at subnational and village levels also equated REDD+ with the activities mentioned above, which is not so surprising, considering that these activities are all part of the CliPAD Village Forestry Component.

The second additional storyline at subnational level was 6) REDD+ copes with climate change. Some respondents explained that deforestation and forest destruction cause climate change. They elaborated further that logging is a polluting activity that emits carbon, carbon dioxide, and other greenhouse gases, which in turn causes the climate to warm. According to this storyline, natural disasters from heat waves and flooding to water scarcity, frost, and bushfires, result from climate change and forest destruction. Trees, on the other hand, are "pollution absorbers", in the words of some respondents. A respondent from the Provincial Forest and Agriculture Office linked this to the global level when he said, "The World is talking about climate change and the world has discovered how carbon heats the planet, causing the climate to change. And we can see it here: climate is changing every day."

The third additional storyline was that 7) REDD+ educates villagers about the importance of climate change and its linkages with forests. Here, the respondents pointed to the need for training villagers in order to make them understand that their livelihood activities, including shifting cultivation and other forest-based livelihood activities, are unsustainable and cause harm to the climate, which in turn affect their livelihoods negatively. The respondent from the Provincial Forest and Agriculture Office, for instance, continued his sentence from above as follows: "We need to educate the villagers to understand climate change and the importance of forests." This storyline overlaps with argument $3 \mathrm{~b}$ about the need to educate local people about sustainable forestry.

\section{$R E D D+$ storylines at the village level}

The storylines we identified at the local level differed significantly between the two villages. Generally, the villagers in Ban Lao-Khmu perceived their own forest related activities as destructive, especially their shifting cultivation practices, and a cause of forest degradation and climate change. They linked this to their own lack of capacities to change their livelihoods. A villager said:

They [the other villagers in Ban Lao-Khmu] abandoned shifting cultivation practices, since now they understand things better. This is because, in the project, the local authorities shared the information about how essential forests are. Why is this so important? Because, in the past, we worked based on our own knowledge especially on shifting cultivation. As a result, the river upstream lacked water and when the water came, there was flooding. This is the impact of shifting cultivation and climate change. 
Many Ban Lao-Khmu villagers reproduced storylines 2, 3, and 7 about REDD+ as a capacity building and educational tool, and about local communities causing deforestation and climate change and being in the need of education. Many villagers, who were members of the village land use and forest committee, articulated strong belief in the "village forest project" (i.e., the CliPAD project) and expected that it would help protect the remaining forest, as in storyline 5 . Not all the villagers in Ban Lao-Khmu, however, shared this belief. Three villagers out of 16 considered the project intervention as unfair, as disregarding their livelihoods, and as depriving future generations of access to forest. Some of the villagers, who in principle approved of the project intervention, considered the size and quality of land allocated for farming inadequate. Thus they added a storyline 8) REDD+ as a project leading to dispossession of forest communities and their loss of control over forests. (Hence the '+/-'in Table 2).

In Ban Hmong, only those who were directly involved with CliPAD project (village head and members of the committee) reproduced the storylines about $R E D D+$ as a village forestry project and REDD+ as a tool for educating villagers. They referred to REDD+ as the "village forestry project" or as "the forest protection project." These respondents understood and framed the project as being about forest protection, forest land allocation and demarcation, defining and implementing village regulations, and limiting shifting cultivation by introducing alternative livelihood activities.

Among the rest of the villagers in Ban Hmong, only a minority could elaborate on the key aims and the different stages of the project, or on the topics discussed in the meetings. Like in Ban Lao-Khmu, ordinary villagers understood the project mainly to be about forest protection, forest allocation, and zone demarcation. Apart from this, their accounts hardly reflected the storylines told at the national and provincial levels at all. Their dominating storyline was the one about REDD+ as a project leading to dispossession of forest communities and their loss of control over forests (Kenney-Lazar 2018). Thus some villagers talked about the project as "sticking the stick in the forest" and "placing the map in the village center", preventing them from going to the forest. They complained about the rules and limitations imposed by the project, they distrusted it and were dissatisfied with the process and results. The following two quotes illustrate their reactions:

This project is unfair. It took the five hectares we used for shifting cultivation as conservation forests. They did not ask us. They only talk to Nai Baan [local word for the village head]. It was Nai Baan who agreed and who signed. Nai Baan does not care, he has land and paddy rice, he does not care. Why should he? I would not either. I will give you an example. During the Ambassador's visit to the village [this event took place approximately two weeks before our fieldwork], why were so few people present? Because some of the villagers said - do not go. If you go, it means that you agree to give and sell the village land and forests" (villager in Ban Hmong).

We cannot be sure, because we have seen it elsewhere, you know. They promise development and roads, but then they take the forest from the villagers. Here, we will not allow this to happen. It happens in all the provinces of Laos. There is a project, the villagers protect the forest, and then the government and investors take the forest. They cheat the villagers. Then the villagers have to pay for cutting trees. We are poor. We cannot pay and buy our forest back" (village elder in Ban Hmong).

One villager in Ban Hmong refused to give an interview saying: "No, I do not want to talk to her. She [the field researcher] is from the project. I am not part of the project. I will not participate in the meetings. I do not want to attend, because then they will say: You participated, you ate the meal, and so it means that you agree to sell the forest." In total ten out of the 15 respondents in this village expressed various degrees of fear and mistrust of the project and the government. ${ }^{6}$

${ }^{6}$ Conflicts between the Hmong ethnic group and the Government of Laos also have roots back in history (Baird 2010; Singh 2012). 
To what extent do the storylines reproduce, change, or reinvent the global meta-discourse about REDD+?

Table 2 summarizes and compares the different storylines at national, subnational, and village levels. The table shows that all the storylines identified at the national level were also present at the subnational levels but mainly absent at the village level. The only storylines that to a certain extent occurred at all levels were about REDD+ as a village forestry project and as a tool for educating the villagers about the link between forestry and climate change.

Table 2, moreover, points to three major findings. First, the global narrative about REDD+ as a tool for creating financial value for carbon stored in forests, or for creating the carbon market, was practically absent at all levels. We take this to indicate that the global discourse on neoliberalism neither dominated, informed, nor shaped the storylines about REDD+. Instead, the respondents at all three levels tended to view REDD+ as just another development forestry project.

Second, the techno-managerial narrative was quite dominant at the national and subnational levels. This is apparent for instance from the first and second storyline but also from CliPAD's general strategy, such as introducing complex village forest management plans.

Third, a majority of the storylines revolved around the role of local communities, and thus can be said to have strong civic (and to a lesser extent environmentalist) elements. Only storyline 3c, however, genuinely reflects the global civic-environmentalist meta-discourse, and this storyline was conspicuously absent at the village level. Even though the formal CliPAD strategy included safeguards and benefit sharing, and even though there were consultations with villagers, the project staff informed us that they avoided mentioning issues such as benefit sharing and REDD+ payments when they introduced REDD+ in the villages. They explained this as a deliberate choice so as to avoid raising villagers' expectations. In this sense, the narratives about poverty alleviation and benefiting the villagers were also absent from project implementation in the villages.

Instead, two different narratives with reference to civic elements emerge from our storylines. The first relates to the perceptions that villagers' activities is the main cause of forest degradation, and hence to the related need to "educate" and change the perceived forest destructive behaviors of villagers, especially of people, who practice shifting cultivation. Even though this narrative was prominent mainly at the national and subnational levels, many of the interviewed villagers (especially in Ban Lao-Khmu) reproduced similar narratives themselves. We refer to this as the anti-civic narrative. The second narrative is about REDD+ as a tool for dispossessing villagers and shifting the control over the forests from the villagers to the state. We refer to this narrative as civic-resentment.

After having "moved" from the global to the local level in Laos, we conclude that REDD+ storylines only vaguely reflect the global meta-discourses about REDD+, while new narratives and argumentations have come up. This raises the question about how the observed patterns of REDD+ policy translation have emerged. In the following section, we discuss this question in the light of Callon's four moments of policy translation.

\section{Understanding the process of REDD+ policy translation}

In this section, drawing on Callon's conceptual framework, we provide our interpretation of how the observed patterns of REDD+ policy translation have emerged in the context of Laos. In particular, we try to understand the absence of the neoliberalist discourse as well as the emergence of the anti-civic and civic resentment narratives at the expense of civic-environmentalism. We begin with the latter.

\section{From civic-environmentalism to anti-civicism and civic resentment}

International development partners equipped with technical knowhow and better access to global REDD+ funds act as obligatory passage points (Callon 1986a,b) for a country interested in implementing REDD+. However, the genuine aims of either domestic policy makers or the international partners are questioned by the civil society and private sector, who suggest that the actors are rather interested in accessing REDD+ funds. International development partners are nonetheless in a good position to problematize REDD+ as they "move" across geographical and policy spaces. As in our CliPAD case, international policy actors come 
with certain predefined problems (deforestation, climate change) and solutions (carbon markets, local participation, FPIC). They draw on the REDD+ technical knowledge when identifying problems and solutions concerning REDD+ policy design and implementation at the national and subnational levels. They also tend to adopt and promote a techno-managerial approach to REDD+. During the process of negotiation and implementation, however, domestic policy actors shape and mold the predesigned problems and technical solutions. The REDD+ process in Laos remains within the scope of the agriculture and forest sector (Dwyer and Ingalls 2015) and government actors in general, excluding marginalized policy actors from decision-making (see also Cole et al. 2018; Ramcilovic-Suominen 2019), the interests and logic of this national political elite dominate the policy processes (see also Ramcilovic-Suominen et al. 2019). These actors naturally focus on activities that do not challenge national government policies and interests. This can be seen both as a result of and a reason for the lack of enrolment and mobilization of wider policy actors (private sector, civil society, local communities) especially at local levels. According to Callon (1986a,b) enrolment and mobilization are imperative for a translation of policy ideas to materialize on the ground.

The domestic political elite in Laos, i.e. national government agencies and to a certain extent the international development partners (e.g. World Bank, FAO and GIZ) problematize deforestation and its drivers primarily as a loss of forest cover due to local small-scale forest uses, e.g. shifting cultivation. In turn, this directs solutions toward land use planning, village forest management plans, and restriction of 'forest destructive' agricultural practices. As a result, national economic interests and foreign investors thriving on the country's forest and land resources are less of a policy target. This can explain the concurrent dominance of techno-managerial and anti-civic narratives at the national and subnational levels. Social safeguards, benefit sharing for local forest communities, protection of community rights, and access to forest and land are bypassed because they are politically sensitive issues (Ramcilovic-Suominen et al. 2019) that REDD+ cannot or has no time, mandates, or tools to address.

The techno-managerial and anti-civic narratives are also strongly prevalent at the national level during interessement. In our case, donor funding and investments in REDD+ played a major role in motivating domestic policy actors. In practice, through REDD+ pilot projects, these funds have translated into efforts for more sustainable forest management accompanied by the existing efforts to advance forest land use planning, mapping, demarcation, and allocation - as was communicated by the domestic policy actors. The funding and capacity building attract not only national but also the provincial and district level governmental agencies, where there is a significant pressure to perform in terms of curbing shifting cultivation and to protect forests in remote villages. The sub-national actors similarly problematized deforestation and forest degradation as phenomena caused by poverty and lack of alternatives and knowledge among villagers, which resulted in translating REDD+ as a village forestry project and a tool to educate villagers about sustainable use of forest and climate change. However, the lower on the governance hierarchical ladder, the lesser is the degree of interessement and especially engagement in the process. ${ }^{7}$

Even though the situation differed between the two villages, there were also similarities between them. Thus, in both of the villages, problematization and interessement as strategies and moments of translation materialized in a top-down manner, heavily mediated and funded by the pilot project, the provincial and district forestry officers, and the project implementing staff. These policy actors presented REDD + as a possible solution to forest degradation, and offered payments to the villagers for carrying out forest management activities and supported 'alternative livelihoods' (i.e. non-forest dependent livelihood activities). As mentioned, the FPIC process engaged village authorities, villagers, and mass organizations such as the Lao Front for National Construction and the Lao Women Union (GIZ 2016; Koch et al. 2015). According to CliPAD staff, the mass organizations did a good job in communicating REDD+ to villages; however, they are not independent civil society organizations as requested in the FPIC, but represent a formal part of the Lao Peoples' Revolutionary Party (LPRP) and the state (Creak and Barney 2018; Mustalahti et al. 2017; Stuart Fox 2005). The emergence of the civic-resentment narrative is probably due to the problems and solutions brought from

\footnotetext{
7 The majority of interviewed key REDD+ policy actors at subnational levels showed confusion about the instrument and especially about their roles in it.
} 
outside, leaving the villagers' interpretations, beliefs, and concerns unrepresented. Rather, the project in reality tended to approach villagers as passive participants in need of information, consultation, training, and education.

\section{Neoliberalist ideas in REDD+}

Given the claims that neoliberalism is a central element of REDD+ (Dressler et al. 2016; Fletcher et al. 2016, 2017), the absence of the private forest sector in in our study, both international and national, is a revealing finding. The private sector actors explained their lack of interest and engagement in REDD+ precisely by referring to the lack of market demand for carbon credits, the low market price for carbon, and the high costs of carbon verification methodologies. This may indicate that - unlike actors from the government and international development partners, who mainly approached REDD+ as a donor funded policy instrument - the private sector framed REDD+ as a carbon market mechanism, which, however, has little potential to take off. They lacked incentives to engage. Instead, they played a "wait-and-see" game, waiting for better opportunities and emergence of competitive carbon markets. While policy actors at the global level initially coined REDD+ as a mechanism that creates incentives for forest users to trade carbon stored in trees, up until now REDD+ has in reality been a donor-funded instrument with little incentives for carbon trading, which could explain the absence of neoliberalist storylines.

In Callon's terms, however, we also interpret the dissolving of neoliberalist ideas - at least as far as carbon trading is concerned - as a lack of policy translation in particular during the moments of interessement and enrolment. Concerning interessement, REDD+ payments in Laos are non-lucrative and highly uncertain ${ }^{8}$, and REDD+ proponents therefore cannot meaningfully refer to such payments as a credible advantage when communicating REDD+ to the private sector and the villagers. In our study areas, the project implementers purposefully did not mention REDD+ performance-based payments and benefit sharing when communicating the project to the villagers. Enrolment of a wider spectrum of actors, including the private sector and the civil society, is also largely missing in the process (see also Mustalahti et al. 2017). It is, in other words, a handful of bureaucrats at the central level and the project partners that define REDD+ implementation in the pilot project areas. While the Government in Laos aimed at the "creation of incentive mechanisms to attract the private sector into sustainable forest development and forest landscape management" (GOL 2018: 66), the private sector kept pointing to low carbon prices and lack of profitability in REDD+. Further, the private sector respondents pointed to the lack of interaction and mutual understanding between the government and the private sector.

Finally, as far as we can see, the payment for emission reductions associated with REDD+ make little sense, particularly at the local level. This is worth highlighting because REDD+ in Laos, as in other countries in Southeast Asia (Milne et al. 2019), is designed to address village forest uses, and therefore to materialize through actions by the villagers. However, local people are detached from global REDD+ planning and design processes as well as from the global carbon markets (see also Massarella et al. 2018; Ramcilovic-Suominen et al. 2019). The REDD+ pilot projects, for better or worse, do not even introduce the idea of REDD+ payments to the villagers. Even if the local people were aware of REDD+ payments, it would be difficult for them to meet the market requirements for costly verification, and to approach these markets and REDD+ payments. These findings, combined with the general lack of competitiveness of REDD+ compared to other land uses (Fletcher et al. 2017) imply that the idea of price setting for carbon stored in trees remains a distant technocratic and neoliberal idea that is irrelevant in the local context.

Provision of donor aid as a way to boost REDD+ competitiveness, however, appears to have benefited the bureaucrats, development partners, and international and domestic consultants. Civil society and the private sector remain excluded from REDD+ process and the local people from any financial benefits. Our findings suggest that the neoliberal discourse has evaporated from domestic REDD+ implementation. Hence, while carbon payments and carbon voluntary markets may not be in place, the neoliberal ideology of forest governance system continues within REDD+, with donor funds and aid that benefit a few. This is in accordance

\footnotetext{
${ }^{8}$ For details on this aspect in Laos, see Ramcilovic-Suominen 2019.
} 
with scholarly debate on the issue, including among others Fletcher et al. (2016, 2017), Dressler et al. (2015) and Lund et al. (2017).

\section{Conclusion: what are the implications for REDD+ and its outcomes?}

The lack of translation of global REDD+ discourses can be explained by the lack of enrolment and mobilization of a wider spectrum of policy actors and local communities, which are a prerequisite for effective policy translation. Partial enrollment and a lack of mobilization of actors were observed at the central policy level. But they were especially scant at the subnational and local levels, where a handful of governmental officials, village heads and members of village committees were enrolled in the process and mobilization was widely lacking. The identified storylines suggest a number of factors that may have obstructed enrolment and mobilization, including:

1) project culture associated with REDD+ donor funding (storyline \#4),

2) resources spent on technical capacity for selected policy actors (storyline \#2),

3) selective targeting of activities and actors as drivers of deforestation (storylines \#3,5,7), and

4) resentment and lack of trust at the local levels (storyline \#8).

Some of these factors resonate with those identified by Milne et al. (2019). The majority of studies we reviewed suggest that policy actors and discourse coalitions promoting non-carbon benefits, social safeguards and equity are weaker than those promoting technical and market dominating narratives (Brockhaus et al. 2014; Di Gregorio et al. 2017; McElwee 2016, 2017; Milne et al. 2019). In Laos, discourse coalitions able to construct storylines related to non-carbon benefits are yet to emerge. While the resentment against the REDD+ instrument existed among some villagers, and to some extent among international and domestic civil society activists, these actors lacked the common line of argumentation and interests needed to form cohesive storylines and discourse coalitions.

REDD+ implementation in Laos is predominantly about centrally driven policy and institutional reform that follows external, technical and scientific concepts and practices. This, coupled with the lack of attention to the non-carbon benefits and standards, and the lack of alternative discourse-coalitions, implies that REDD+ in Laos is likely to cause further limitations and struggles to local residents and villagers relying on forests for subsistence, farming practices, and livelihoods.

\section{References}

Aicher, C. 2014. Discourse practices in environmental governance: social and ecological safeguards of REDD. Biodiversity Conservation 23: 3543-3560.

Albrecht, M., J. Kortelainen, M. Sawatzky, J. Lukkarinen and T. Rytteri. 2017. Translating bioenergy policy in Europe: mutation, aims and boosterism in EU energy governance. Geoforum 87: 73-84.

Arhin, A.A. 2014. Safeguards and dangerguards: a framework for unpacking the black box of safeguards for REDD+. Forest Policy Economics 45: 24-31.

Arts, B., M. Appelstrand, D. Kleinschmit, H. Puelzl, I. Visseren-Hamakers, R. Eba'a Atyi, T. Enters, K. McGinley and Y. Yasmi. 2010. Discourses, actors and instruments in international forest governance. In J. Rayner, A. Buck and P. Katila (eds.). Embracing complexity: meeting the challenges of international forest governance. Vienna: International Union of Forest Research Organizations.

Bäckstrand, K. and E. Lövbrand. 2006. Planting trees to mitigate climate change: contested discourses of ecological modernization, green governmentality and civic environmentalism. Global Environmental Politics 6(1): 50-75.

Baird, I.G. 2010. The Hmong come to Southern Laos: local responses and the creation of racialized boundaries. Hmong Studies Journal 11: 1-38. 
Benjaminsen, G. 2017. The bricolage of REDD+ in Zanzibar: from global environmental policy framework to community forest management. Journal of Eastern African Studies. 11(3): 506-525.

Brockhaus, M., M. Di Gregorio and R. Carmenta. 2014. REDD+ policy networks: exploring actors and power structures in an emerging policy domain. Ecology and Society 19(4): 29.

Callon, M. 1986a. The sociology of an actor-network: the case of the electric vehicle. In Callon, M., A. Rip and J. Law (eds.). Mapping the dynamics of science and technology: sociology of science in the real world. London: MacMillan Press. Pp. 19-34.

Callon, M. 1986b. Some elements of a sociology of translation: domestication of the scallops and the fishermen of St. Brieuc Bay. In Law, J. (ed.). Power, action and belief: a new sociology of knowledge? London: Routledge and Kegan Paul. Pp. 196-233.

Canby, K., G. Silva-Chávez, J. Breitfeller, C. Lanser, M. Norman and B. Schaap. 2014. Tracking REDD+ finance: 2009-2012 - finance flows in seven REDD+ countries. Washington, DC: Forest Trends.

Chomba, S., J. Kariuki, J.F. Lund and F. Sinclair. 2016. Roots of inequity: tenure arrangements and carbon benefits in the Kasigau Corridor, Kenya. Land Use Policy 50: 202-213.

Cole, R., G. Wong, M. Brockhaus, M. Moeliono and M. Kallio. 2017. Objectives, ownership and engagement in 878 Lao PDR's REDD+ policy landscape. Geoforum 83: 91-100.

Creak, S. and K. Barney. 2018. Party-state governance and rule in Laos. Journal of Contemporary Asia. 48(5): 693-716.

Dawson, N.M., M. Mason, J.A. Fisher, D.M. Mwayafu, H. Dhungana, H. Schroeder and M. Zeitoun. 2018. Norm entrepreneurs sidestep REDD+ in pursuit of just and sustainable forest governance. Sustainability 10(6): 1726.

Di Gregorio, M., C.T. Gallemore, M. Brockhaus, L. Fatorelli and M. Efrian. 2017. How institutions and beliefs affect environmental discourse: evidence from an eight-country survey on REDD+. Global Environmental Change 45: 133-150.

Di Gregorio, M., M. Brockhaus, T. Cronin, E. Muharrom, L. Santoso, S. Mardiah and M. Büdenbender. 2013. Equity and REDD+ in the media: a comparative analysis of policy discourses. Ecology and Society 18(2): 39.

Dolowitz, D. 2009. Learning by observing: surveying the international arena. Policy and Politics 37(3): 31734.

Dolowitz, D.P. and D. Marsh. 2000. Learning from abroad: the role of policy transfer in contemporary policy making. Governance 13(1): 5-24.

Dressler, W.H., S. Mahanty, J. Clendenning and P. To. 2015. Rearticulating governance through carbon in the Lao PDR? Environment and Planning C: Politics and Space 33: 1265-1283.

Duchelle, A.E., G. Simonet, W.D. Sunderlin and S. Wunder. 2018. What is REDD+ achieving on the ground? Current Opinion in Environmental Sustainability 32: 134-140.

Dwyer, M. and M. Ingalls. 2015. REDD at the crossroads: choices and tradeoffs for 2015-2020 in Laos. Bogor, Indonesia: Center for International Forestry Research.

Ece, M., J. Murombedzi and J. Ribot. 2017. Disempowering democracy: local representation in community and carbon forestry in Africa. Conservation and Society 15(4): 357-370.

EDF (Environmental Defense Fund) and Forest Trends. 2018. Mapping forest finance: a landscape of available sources of finance for REDD+ and climate action in forests. New York: Environmental Defense Fund.

Evans, M. 2009. Policy transfer in critical perspective. Policy Studies 30(3): 243-268.

Ferguson, J. and L. Lohmann. 1994. The anti-politics machine: 'development' and bureaucratic power in Lesotho. The Ecologist 24(5): 176-181.

Fletcher, R., W. Dressler, B. Büscher and Z.R. Anderson. 2016. Questioning REDD and the future of market based conservation. Conservation Biology 30(3): 673-675.

Fletcher, R., W. Dressler, B. Büscher and Z.R. Anderson. 2016. Debating REDD+ and its implications: reply to Angelsen et al. Conservation Biology 31(3): 721-723. 
Fox, J., J.C. Castella and A.D. Ziegler. 2011. Swidden, rubber and carbon: can REDD work for people and the environment in Montane Mainland Southeast Asia? Global Environmental Change 29: 318-326.

Freeman, R. 2009. What is "translation"? Evidence and Policy 5(4): 429-447.

GIZ (German Development Agency). 2017. Guidelines for conducting free prior informed consent (FPIC). Houaphan Province, Lao People's Democratic Republic: Climate Protection through Avoided Deforestation (CliPAD) Project.

GIZ (German Development Agency). 2016. Village Forest Management Planning Guideline. Lao PDR: Climate Protection through Avoided Deforestation.

GOL (Government of Laos). 2018. Readiness fund REDD+ country participants progress report Lao PDR. Forest Carbon Partnership Facility.

Gupta, A., E. Lövbrand, E. Turnhout and M.J. Vijge. 2012. In pursuit of carbon accountability: the politics of REDD+ measuring, reporting and verification systems. Current Opinion in Environmental Sustainability 4:726-731.

Hajer, M.A. 1993. Discourse coalitions and the institutionalization of practice: the case of acid rain in Great Britain. In Fischer, F. and J. Forester (eds.). The argumentative turn in policy analysis and planning. Durham, North Carolina: Duke University Press. Pp. 43-76.

Hajer, M.A. 1995. The politics of environmental discourse: ecological modernization and the policy process. Oxford: Clarendon.

Hajer, M.A. 2005. Coalitions, practices and meaning in environmental politics: from acid rain to BSE. In Howarth D. and J. Torfing (eds.). Discourse theory in European politics. London: Palgrave Macmillan. Pp. 297-315.

Horowitz, L.S. 2012. Translation alignment: actor-network theory, resistance, and the power dynamics of alliance in New Caledonia. Antipode 44: 806-827.

Ingalls, M., P. Meyfroidt, P. To, M. Kenney-Lazar and M. Epprecht. 2018. The transboundary displacement of deforestation under REDD+: problematic intersections between the trade of forest-risk commodities and land grabbing in the Mekong region. Global Environmental Change 50: 255-267.

Jasanoff, S. and B. Wynne. 1998. Science and decision making. In Rayner, S. and E. L. Malone (eds.). Human choice and climate change. Columbus: Battelle Press. Pp. 1-87.

Kenney-Lazar, M. 2018. Governing dispossession: relational land grabbing in Laos. Annals of the American Association of Geographers 108 (3): 679-694.

Khatri, D.B., K. Marquardt, A. Pain and H. Ojha. 2018. Shifting regimes of management and uses of forests: what might REDD+ implementation mean for community forestry? Evidence from Nepal. Forest Policy and Economics 92:1-10.

Koch, S. 2017. The struggle over Lao PDR's forests: new opportunities for improved forest governance? Pacific Geographies 47: 4-13.

Koch, S., J. Kallabinski and T. Okfen. 2015. Village Forest Management Agreements (VilFoMA) as a performance-based payment scheme under REDD + in Lao PDR. Paper presented at XIV World Forestry Congress. Durban, South Africa: World Forestry Congress.

Latour, B. 1999. On recalling ANT. In Law and Hassard (eds.). Actor-network theory and after. Oxford: Blackwell Publishers. Pp. 15-25.

Latour, B. 2005. Reassembling the social: an introduction to actor-network theory. New York: Oxford University Press.

Law, J. 1999. After ANT: complexity, naming and topology. In Hassard, J and J. Law. (eds.). Actor-network theory and after. Oxford: Blackwell/Sociological Review. Pp. 1-14.

Lee, D. and T. Pistorius. 2015. The impacts of international REDD+ finance. San Francisco: Climate and Land Use Alliance. 
Lendvai, N. and P. Stubbs. 2007. Policies as translation: situating trans-national social policies. In Hodgson, S. and Z. Irving (eds.). Policy reconsidered: meaning, politics and practices. Bristol: The Policy Press. Pp. 173-189.

Lund, J.F., E. Sungusia, M.B. Mabele and A. Scheba. 2017. Promising change, delivering continuity: REDD as conservation fad. World Development 89: 124-139.

MAF (Ministry of Agriculture and Forestry). 2018. promoting redd+ through governance, forest landscapes and livelihoods in Northern Lao PDR. Forest Carbon Partnership Facility.

Massarella, K., S.M. Sallu, J.E. Ensor and R. Marchant. 2018. REDD+, hype, hope and disappointment: the dynamics of expectations in conservation and development pilot projects. World Development 109: 375385.

McDermott, C. 2014. REDDuced: from sustainability to legality to units of carbon-the search for common interests in international forest governance. Environmental Science and Policy 35: 12-19.

McElwee, P. 2016. Forests are gold: trees, people, and environmental rule in Vietnam. Seattle: University of Washington Press.

McElwee, P., N.H. Van, N.V. Dung, T.H. Nghi, L.T.V. Hue, N.P. Tuyen and V.D. Huong. 2017. Using REDD+ policy to facilitate climate adaptation at the local level: synergies and challenges in Vietnam. Forests 8: 11.

Mertz, O., K. Grogan, D. Pflugmacher, G. Lestrelin, J.C. Castella, T. Vongvisouk, C. Hett, R. Fensholt, Z. Sun, N. Berry and D. Müller. 2018. Uncertainty in establishing forest reference levels and predicting future forest-based carbon stocks for REDD+. Journal of Land Use Science 13(1-2): 1-15.

Milne, S., M. Milne, F. Nurfatriani and L. Tacconi. 2016. How is global climate policy interpreted on the ground? Insights from the analysis of local discourses about forest management and REDD+ in Indonesia. Ecology and Society 21(2): 6.

Milne, S., S. Mahanty, P. To, W. Dressler, P. Kanowski and M. Thavat. 2019. Learning from 'actually existing' REDD+: a synthesis of ethnographic findings. Conservation and Society 17(1): 84-95.

Mukhtarov, F. 2014. Rethinking the travel of ideas: policy translation in the water sector. Policy and Politics 42(1): 71-88.

Mustalahti, I., M. Cramm, S. Ramcilovic-Suominen, S. and Y.T. Tegegne. 2017. Resources and rules of the game: participation of civil society in REDD+ and FLEGT-VPA processes in Lao PDR. Forests 8(2): 50.

Myers, R., A.M. Larson, A. Ravikumar, L.F. Kowler, A. Yang and T. Trench. 2018. Messiness of forest governance: how technical approaches suppress politics in REDD+ and conservation projects. Global Environmental Change 50: 314-324.

Nathan, I. and M. Pasgaard. 2017. Is REDD+ effective, efficient, and equitable? Learning from a REDD+ project in Northern Cambodia. Geoforum 83: 26-38.

Nielsen, T.D. 2014. The role of discourses in governing forests to combat climate change. International Environmental Agreements: Politics, Law, and Economics 14(3): 265-280.

Pasgaard, M. 2015. Lost in translation? How project actors shape REDD+ policy and outcomes in Cambodia. Asia Pacific Viewpoint 56(1): 111-127.

PRAP. 2017. PARP for Houaphan Province. (Provincial REDD+ Action Plan). Lao PDR.

Ramcilovic-Suominen, S. 2019. REDD+ as a tool for state territorialization: managing forests and people in Laos. Journal of Political Ecology 26: 264-281.

Ramcilovic-Suominen, S., M. Lovric and I. Mustalahti. 2019. Mapping policy actor networks and their interests in the FLEGT Voluntary Partnership Agreement in Lao PDR. World Development 118: 128-148.

Rantala, S., T. Kontinen, K. Korhonen-Kurki and I. Mustalahti. 2015. Equity in REDD+: varying logics in Tanzania. Environmental Policy and Governance 25(3): 201-212.

Saeed, A.R., C. McDermott and E. Boyd. 2018. Examining equity in Ghana's national REDD+ process. Forest Policy and Economics 90: 48-58. 
Sanders, A.J.P., H. Hyldmo, R.D.H. Prasti, R.M. Ford, A.M. Larson and R.J. Keenan. 2017. Guinea pig or pioneer: translating global environmental objectives through to local actions in Central Kalimantan, Indonesia's REDD+ pilot province. Global Environmental Change 42: 68-81.

Simonet, G., J. Suberview, D. Ezzine-De-Blas, M. Cromberg and A. Duchelle. 2018. Effectiveness of a REDD project in reducing deforestation in the Brazilian Amazon. American Journal of Agricultural Economics 101(1): 211-229.

Singh, S. 2012. Natural potency and political power: forests and state authority in contemporary Laos. Honolulu: University of Hawaii Press.

Stuart-Fox, M. 2005. Politics and reform in Lao People's Democratic Republic. Perth: Asia Research Centre, Murdoch University.

UNFCCC. 2010. Report of the Conference of the Parties on its sixteenth session. United Nations.

UNFCCC. $2015 . \quad$ Paris Agreement. [accessed $\quad$ January 12019 ]. https://unfccc.int/sites/default/files/english_paris_agreement.pdf (Accessed January 2019)

UN-REDD 2018. About REDD+. Accessed 18th January 2019.

Vijge M.J., M. Brockhaus, M. Gregorio and E. Muharrom. 2016. Framing national REDD+ benefits, monitoring, governance and finance: a comparative analysis of seven countries. Global Environmental Change 39: 57-68.

Vijge, M.J. 2015. Competing discourses on REDD+: global debates versus the first Indian REDD+ project. Forest Policy and Economics 56(C) 38-47.

Vongvisouk, T., G. Lestrelin, J.C. Castella, O. Mertz, R.B. Broegaard and S. Thongmanivong. 2016. REDD+ on hold: lessons from an emerging institutional setup in Laos. Asia Pacific Viewpoint 57(3): 393-405.

Winkel, G., S. Leipold, K. Buhmann, B. Cashore, W. De Jong, I. Nathan, M. Sotirov and M. Stone. 2017. Narrating illegal logging across the globe: between green protectionism and sustainable resource use. International Forestry Review 19: 81-97. 